\title{
EDITORIAL
}

\section{Nazareno Strampelli, the 'Prophet' of the green revolution}

\author{
S. SALVI ${ }^{1 *}$, O. PORFIRI ${ }^{2}$ AND S. CECCARELLI ${ }^{3}$ \\ ${ }^{1}$ National Research Institute on Food and Nutrition (INRAN), Rome, Italy \\ ${ }^{2}$ Agronomist Consultant, Via Valleresco 24, 62010 Urbisaglia, Italy \\ ${ }^{3}$ Consultant, 40 Impasse Suzanne Bernard, 34070 Montpellier, France
}

(Received 18 October 2011; revised 9 December 2011; accepted 24 February 2012; first published online 21 March 2012)

\section{SUMMARY}

23 January 2012 marked 70 years since the death of the Italian plant breeder Nazareno Strampelli (1866-1942), one of the most important plant geneticists of the 20th century. During the first 30 years of what is known as the 'short century', Strampelli was among the first, in Europe and in the world, to systematically apply Mendel's laws to plant breeding, particularly to wheat breeding which resulted in varieties characterized by rust resistance, early flowering and maturity and short straw. Due to Strampelli's varieties Italian wheat production doubled, an achievement that during the fascist regime was referred to as the 'Wheat Battle'.

Some of Strampelli's wheats, such as Mentana, Ardito and San Pastore, were used as parents in the breeding programmes of several countries after the Second World War; they also had a key role in the first phase of Norman Borlaug's Green Revolution, being instrumental in the development of the high-yielding varieties of the future Nobel Peace Laureate.

A century after the key cross in which Strampelli, 30 years before Borlaug, used the genes for short straw and earliness in wheat breeding, his name and his work are not known and appreciated as they deserve, despite the recent evidence that the resistance to the new rust races could derive from the very same resistance genes identified by the Italian breeder at the beginning of the 20th century.

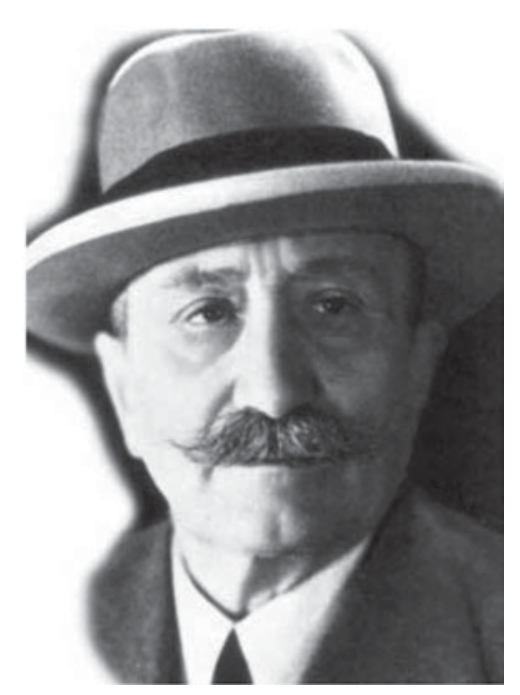

Nazareno Strampelli 1866-1942

\footnotetext{
* To whom all correspondence should be addressed. Email: sergiosalvi@hotmail.com
}

\section{BIOGRAPHY AND PROFESSIONAL CAREER}

Nazareno Strampelli was born on 29 May 1866 in Castelraimondo (Macerata), in Marche (Central Italy) where his parents were landowners. He spent his early years on a farm where the dominant crop was bread wheat. At that time, farmers grew tall varieties which lodged frequently; in addition, their late maturity made them susceptible to drought stress during grain filling. Rust susceptibility was an additional cause of low yields, which seldom exceeded $0 \cdot 8-1 \cdot 0$ t/ha.

In a situation where the life of both farmers and land owners was constantly affected by the low yield of their main crop, the young Strampelli became attracted to agricultural studies. After attending school in Camerino (close to Macerata), he enrolled in the Scuola Superiore di Agricoltura (High School of Agriculture) in Portici (Naples), and then obtained a Degree in Agriculture at the University of Pisa in 1891, graduating with the highest grade (130/130). Having a good background in chemistry, he got a job as Director 
of the Chemistry Lab in the Argentario mines in Tuscany, then as teacher in a number of high schools in Camerino and eventually as Assistant to the Chair of Chemistry in the University of Camerino.

In 1900, Strampelli attempted his first crosses between the two bread wheat varieties Rieti and Noè, rust-resistant and lodging-resistant, respectively. The specific objective was to combine the two traits (Strampelli 1907a). Strampelli was unaware of Mendel's work published 35 years earlier and rediscovered just that year by Correns, de Vries and Tschermak (Correns 1900; De Vries 1900; Tschermak 1900) nevertheless he fully understood the potential of hybridization in plant breeding. This is remarkable because in Italy the predominant breeding method at the time was based on the genealogic selection of naturally occurring desirable types within existing populations, as applied by another important Italian breeder, Francesco Todaro in Bologna. However, to Strampelli the only way to fix a new agronomically useful trait in a given variety (e.g. rust resistance, lodging resistance and earliness) was by crossing that variety with one that constitutively possessed the trait (Strampelli 1932). In 1903, Strampelli successfully applied for the position of Director of the cattedra ambulante of cereal cultivation in Rieti (the Cattedre ambulanti di Agricoltura (Itinerant Chairs of Agriculture), which were for nearly a century the most important Institutions of Agricultural Education addressing, particularly, small farmers: the first was established in Ascoli Piceno (Marche) in 1863). Over time and despite a number of difficulties, the 'cattedra ambulante' was transformed into the Royal Experimental Station of Cereal Cultivation. Eventually, in 1919, Strampelli established and became the Director of the National Institute of Genetics for Cereal Crops (currently part of C.R.A., Council for Research and Experimentation in Agriculture) with their headquarters in Rome. Assisted by his wife, Carlotta Parisani, Strampelli made at least 800 crosses using about 250 bread wheat varieties from all over the world as parents. The objective was to increase the genetic diversity as much as possible to produce new varieties (races was the term used at the time) able to increase national production (Strampelli 1932).

The period 1903-18 was Strampelli's 'golden age' from the point of view of research diversification and number of papers produced (nearly all in Italian). Read today, these papers reveal a research approach that we would define as interdisciplinary, because he would use all available sources of information to tackle a variety of problems. In this period Strampelli published papers not only about genetics but also about microbiology, chemistry (Strampelli 1906a), physics (Strampelli 1906b), plant pathology (Strampelli 1906c) and plant physiology (Strampelli 1907b). However, genetics soon became his predominant interest.

In 1914, Strampelli released his first high-yielding bread wheat variety, named Carlotta Strampelli. However, this variety was not sufficiently early and consequently, after three cropping seasons with exceptionally high yields, it showed its weakness in the first hot and dry summer (Lorenzetti 2000). The solution to the problems that Strampelli was facing was delayed by a few more years.

Among the diverse wheats Strampelli evaluated in Rieti, the Japanese variety Akakomugi particularly attracted his attention. Strampelli obtained a free sample of seeds in 1911 from the Ingegnoli company in Milan (Strampelli 1932). The variety had no agronomic value - Strampelli (1932) used the expression 'of no value for cultivation' - but it had two unique traits: it was short-strawed (possessing the gene Rht8), being just $0.60-0.65 \mathrm{~m}$ tall, and was extremely early maturing (due to the gene Ppd-D1). In 1913, Strampelli crossed the line Selezione 21, derived from the cross between Rieti (rust-resistant) and 'Wilhelmina Tarwe' (high-yielding), with Akakomugi (Bianchi 1995; Borojevic \& Borojevic $2005 a, b)$ and obtained progenies with exceptional (at the time) phenotypes: all the lines derived from this cross involving three parents were in fact much shorter $(0 \cdot 90-1 \cdot 10 \mathrm{~m}$ high) than the traditional varieties (almost double this height) and therefore lodging resistant. In addition, the lines matured 1-3 weeks earlier than the traditional varieties, thus escaping drought stress during grain filling. Eventually, the lines inherited from the parent Rieti showed a high level of rust resistance (Strampelli 1932). Lines derived from this cross became, among others, the varieties Mentana, Ardito, Villa Glori and Damiano, which soon became famous in other countries, notably Argentina and China.

After 1925, Strampelli's wheats became the main instruments of the Battaglia del Grano (the Wheat Battle), the propaganda slogan that the Fascist Regime used to define the campaign to reach wheat selfsufficiency in Italy. The National Institute of Genetics for Cereal Crops, of which Strampelli was the Director, was obviously in charge of implementing the campaign. A unique characteristic of the Institute was the network of research stations and experimental fields 
spread throughout the country from Polesine to Puglia and from Lazio to Sardinia, which allowed wide testing of Strampelli's bread wheats in a multitude of different locations. The objective of the Wheat Battle was reached in the following 10 years and the national yield of bread wheat increased from 4.4 million tonnes in 1922 to 8.0 million tonnes in 1933 (Lorenzetti 2000).

In 1925, Strampelli joined the National Fascist Party, a decision that eventually affected both his personal reputation and his scientific work after the Second World War. In 1929, he was nominated Senator of the Kingdom for his scientific achievements and the Fascist Regime bestowed upon him National Honours' in recognition of his services to the country in the Wheat Battle. However, this recognition in Italy was not reflected internationally, due to the nationalization of his science: the time of the Wheat Battle coincided with the period of least production of scientific papers and Strampelli's almost complete absence at international conferences.

Nazareno Strampelli died in Rome on 23 January 1942 before he could publicly abjure his membership in the Fascist Regime, as done by many of his colleagues who survived the end of fascism and the Second World War.

\section{STRAMPELLI'S WHEATS IN THE WORLD}

By the late 1940s, Strampelli's wheats were grown on 20 million ha in China, the first country in the world where the wheat varieties created by the Italian geneticist were adopted on a large scale (Lorenzetti 2000). Strampelli's wheats, particularly Mentana, were the basis of the wheat breeding programmes in many other countries. In Argentina, Ardito was used to create the variety Klein 33, which became the basis of the USSR breeding programme, generating the variety Bezostaja 1, which in turn was used together with San Pastore in the breeding programme of the former Yugoslavia (Worland et al. 1998; Borojevic \& Borojevic 2005a, b). From Brazil, the variety Frontana (derived from a cross with Mentana) as well as the variety Mentana appeared in Norman Borlaug's Mexican programme: thus Mentana was part of the pedigree of Penjamo 62, Yaqui 48, Lerma 50, Escobar and Supremo. Eventually, Canada and Australia also introduced genotypes derived from Mentana into their breeding programmes (Worland et al. 1998; Kolmer et al. 2008).
The widespread recognition by wheat specialists of the diffusion and use of Strampelli's wheats came late. However, the evidence of Strampelli's role as a precursor of the Green Revolution has spread in international scientific circles since the 1970s. The testimony of the Italo-Argentinean agronomist Josè Vallega (1909-78) is of particular interest to those seeking to understand the relationships between Strampelli's wheats and the Green Revolution: on a number of occasions he emphasized Strampelli's role as a precursor of the Green Revolution and in particular the fact that the rust resistance of Mentana was known to the research group of Elvin C. Stakman. In fact Vallega himself, as a guest scientist in 1938 at the University of Minnesota (Vallega 1955, 1966), identified this most famous Strampelli variety as one of the first sources of resistance to the highly virulent race 15B of Puccinia graminis. The race appeared on the American continent in that very same year (Vallega 1940, 1966, 1974).

At the time Vallega made this observation, Norman Borlaug started his MSc thesis under Stakman's supervision (Hesser 2006). It is therefore easy to hypothesize that Borlaug knew the wheat Mentana so well that when he started his work 10 years later as pathologist with the Rockefeller Foundation Project in Mexico (1943-61), Borlaug decided to use Mentana-related genotypes in breeding for rust resistance, one of the main priorities of the project. This hypothesis is supported by the fact that Borlaug himself mentions Mentana, together with the varieties Marroqui and Gabo, as one of the key genotypes in his breeding work since the 1940s (Borlaug 1968).

A substantial difference between Strampelli's and Borlaug's breeding methodologies is related to the way they obtained photoperiod insensitivity. Breeding for earliness was one of the pillars of Strampelli's breeding programmes, which he pursued since the very beginning of his work (Strampelli 1907b) as a trait that would allow the wheat crop to escape the devastating effects of drought during the filling period so common in the Mediterranean basin. In contrast, photoperiod insensitivity to Borlaug was an 'unplanned collateral effect' of 'shuttle breeding', and Borlaug himself had to admit that this was a case of serendipity at a time when little was known about the genetic control of photoperiod insensitivity (Borlaug 2007). Shuttle breeding is a technique by which, exploiting both the longitudinal and the altitudinal diversity of Mexico, it was possible to plant and harvest wheat twice a year, once in the far North at sea level and once in Central Mexico at nearly 
2200-2600 m asl. This was done to accelerate the breeding process, because of the urgency to develop rust-resistant material through hybridization and selection. However, under these conditions only those genotypes insensitive to photoperiod were able to reproduce, hence the collateral effect. These genotypes were able to grow at various latitudes and were therefore defined 'widely adapted'. This term has generated considerable confusion between adaptation in a geographical sense (which was what Borlaug's genotypes had) and adaptation in an environmental sense (which would indicate an ability to grow in contrasting environmental conditions - it is now widely recognized that these genotypes lacked this ability) and has most probably enhanced the international reputation of Borlaug's work.

Borlaug recognized that in his case the photoperiod insensitivity was merely a collateral effect. This is in contrast to the perception by Strampelli that it was necessary to tackle the problem of earliness from a genetic point of view - ignored by Borlaug - by using the Japanese variety Akakomugi. Therefore, not only the rust resistance but also the photoperiod insensitivity of Borlaug's wheats is the direct effect of adopting Mentana-based genotypes in the Rockefeller programme.

To that end, a recent study (Guo et al. 2010) has shown that haplotype I of the Ppd-D1 gene from the Akakomugi used by Strampelli is still very frequent in the bread wheat varieties grown today in Mexico and directly derived from those generated during the first phase of the Green Revolution.

Current international wheat science continues to demonstrate how topical are the innovations introduced by Strampelli. In the 1980s and 1990s, the work of Tony Worland and colleagues at the John Innes Centre (Norwich, UK) on Rht8 and Ppd-D1 genes (Gale et al. 1982; Worland \& Law 1986; Worland et al. 1998) showed the role that Strampelli's varieties played in modern wheat breeding. More recently, in what can be defined as a second round of Strampelli's re-discovery, a major role is played by an allele of the Lr34 gene which gives a durable rust resistance (Lagudah et al. 2009). This allele, which today is considered of fundamental importance in planning global wheat breeding for rust resistance, descends from 'Ardito' and 'Mentana' and is present in most of the varieties grown in the world (Kolmer et al. 2008).

Today, it is finally possible to fully understand to what an extent the Green Revolution has benefitted from the preparatory work done by Strampelli who,
30 years earlier than Borlaug, achieved exactly the same scientific results with the same international range. It is the current authors' view that the major scientific merit of Strampelli was the extraordinary innovation of his scientific work, which was not the case of those who followed, including Borlaug, who had the advantage of using the genetic material assembled by the Italian geneticist. We are confident that it is not an overstatement to say that without Strampelli's contribution, the Green Revolution would have been very different.

\section{CONCLUSION}

The recognition of the global importance of Strampelli's results in wheat breeding and of the positive spill-over effects on modern plant breeding has progressed (Braun et al. 1997; Borojevic 2003). However, even today few seem to agree that the Italian geneticist deserves recognition as a genuine scientist: this was questioned by his contemporaries because of his low production of scientific papers and the fact that a large amount of research work, including that on forage crops, horticultural crops and industrial crops, was never published (Strampelli 1932).

The extraordinary relevance of Strampelli's work is the best testimony of the scientific value of the man and fully justifies both his role as a precursor of the Green Revolution and the status of genuine scientist that from now on should be universally acknowledged.

\section{REFERENCES}

BIANCHI, A. (1995). Nazareno Strampelli: wheat breeder extraordinaire and father of Italy's 'Green revolution'. Diversity 11, 135-136.

Borlaug, N. E. (1968). Wheat breeding and its impact on world food supply. In Proceedings of the 3rd International Wheat Genetic Symposium (Eds K.W. Finlay \& K.W. Shepherd), pp. 1-36. Canberra, Australia: Australian Academy of Sciences.

Borlaug, N. E. (2007). Sixty-two years of fighting hunger: personal recollections. Euphytica 157, 287-297.

BOROJEVIC, K. (2003). Art and science of Italian wheat breeding and its influence on breeding in South and Central Europe. In Proceeding of the Tenth International Wheat Symposium, Paestum, Italy 2003 (Eds N. E. Pogna, M. Romano, A. E. Pogna \& G. Galterio), pp. 109-113. Rome: Istituto Sperimentale per Cerealicoltura.

BorojeVIC, K. \& BorojeVIC, K. (2005a). Historic role of the wheat variety Akakomugi in Southern and Central European wheat breeding programs. Breeding Science 55, 253-256. 
BorojeVIC, K. \& BorojeVIC, K. (2005b). The transfer and history of 'reduced height genes' (Rht) in wheat from Japan to Europe. Journal of Heredity 96, 455-459.

Braun, H.-J., Altay, F., Kronstand, W. E., Benimal, S. O. S. \& $\mathrm{MCN}_{A B}, \mathrm{~A}$. (1997). Wheat: prospects for global improvement. In Proceeding of the 5th International Wheat Conference Ankara, Turkey, 10-14 June 1996. Developments in Plant Breeding, vol. 6. Berlin: Springer. 582 pages.

Correns, C. (1900). G. Mendel's Regel über das Verhalten der Nachkommenschaft der Rassenbastarde. Berichte der deutschen botanischen Gesellschaft 18, 158-168.

De VRIES, H. (1900). Sur la loi de disjonction des hybrides. Comptes Rendus de 1'Académie des Sciences (Paris) 130, 845-847.

Gale, M. D., Law, C. N., Marshall, G.A., Snape, J.W. \& WORLAND, A.J. (1982). The analysis and evaluation of semi-dwarfing genes in wheat, including a major height reducing gene in the variety 'Sava.'. IAEA Tecdoc: Semidwarf Cereal Mutants and their Use in Cross Breeding 268, 7-23.

Guo, Z., Song, Y., Zhou, R., Ren, Z. \& JIA, J. (2010). Discovery, evaluation and distribution of haplotypes of the wheat Ppd-D1 gene. New Phytologist 185, 841-851.

Hesser, L. F. (2006). The Man who Fed the World: Nobel Peace Prize Laureate Norman Borlaug and his Battle to End World Hunger. Dallas, USA: Durban House.

Kolmer, J.A., Singh, R.P., Garvin, D. F., Viccars, L., William, H.M., Huerta-Espino, J., Ogbonnaya, F. C., Raman, H., Orford, S., Bariana, H.S. \& Lagudah, E. S. (2008). Analysis of the Lr34/Yr18 rust resistance region in wheat germplasm. Crop Science 48, 1841-1852.

Lagudah, E.S., Krattinger, S. G., Herrera-Foessel, S., Singh, R.P., Huerta-Espino, J., Spielmeyer, W., BrownGuedira, G., Selter, L. L. \& Keller, B. (2009). Gene-specific markers for the wheat gene Lr34/Yr18/Pm38 which confers resistance to multiple fungal pathogens. Theoretical and Applied Genetics 119, 889-898.

Lorenzetti, R. (2000). La Scienza del Grano. L'esperienza scientifica di Nazareno Strampelli e la Granicoltura Italiana dal Periodo Giolittiano al Secondo Dopoguerra. Rome: Ministero per i beni e le attività culturali.

Strampelli, N. (1906a). Azione dei Diversi Composti di Manganese ed in Particolare del Minerale Manganesifero del Monte Argentario Usati nella Concimazione delle
Piante, Atti del VI Congresso Internazionale di Chimica Applicata. Rome: Bertero.

StrAmpelLI, N. (1906b). Di una speciale azione elettrica sulle piante, Atti del VI Congresso internazionale di chimica applicata. Rome: Bertero.

Strampelli, N. (1906c). Esperienze intorno alla malattia del frumento dovuta all'Ustilago carbo, Rendiconti della Reale Accademia Nazionale dei Lincei. Classe di Scienze Fisiche, Matematiche e Naturali 15, 211-213.

Strampelli, N. (1907a). Alla Ricerca e Creazione di Nuove Varietà di Frumenti a Mezzo dell'lbridazione. Rome: Tipografia dell'Unione Cooperativa Editrice di Roma per conto della Regia Stazione di Granicoltura di Rieti.

Strampelli, N. (1907b). Alcune anomalie di forma nelle infiorescenze del frumento. Le Stazioni Sperimentali Agrarie Italiane 60, 121-127.

Strampelli, N. (1932). Origini, sviluppi, lavori e risultati. Milano, Italy: Istituto Nazionale di Genetica per la Cerealicoltura, Alfieri \& Lacroix.

TsChermak, E. (1900). Über künstliche Kreuzung bei Pisum sativum. Zeitschrift für das landwirtschaftliche Versuchswesen in Österreich 3, 465-555.

ValleGA, J. (1940). Especializacion fisiologica de Puccinia graminis tritici en la Argentina, Chile y Uruguay. Revista Argentina de Agronomia 7, 196-220.

VallegA, J. (1955). Wheat rust races in South America. Phytopathology 45, 242-246.

ValleGA, J. (1966). Nazareno Strampelli. $1^{\circ}$ Centenario della Nascita. Rome: Ramo Editoriale Degli Agricoltori.

VALLEGA, J. (1974). Historical perspective of wheat breeding in Italy 4, Proceedings of the fourth FAO/Rockefeller Foundation Wheat Seminar, Tehran, Iran, 21 May-2 June 1973. p. 115-126.

Worland, A.J. \& LaW, C. N. (1986). Genetic analysis of chromosome 2D of wheat. I. The location of genes affecting height, day length insensitivity, hybrid dwarfing and yellow rust resistance. Zeitschrift fur Pflanzensuchtung 96, 331-345.

Worland, A. J., Korzun, V., Ganal, M.W., Roder, M. \& LAW, C. N. (1998). Genetic analysis of dwarfing gene Rht8 in wheat. Part II. The distribution and adaptive significance of allelic variants at the Rht 8 locus of wheat as revealed by microsatellite screening. Theoretical and Applied Genetics 96, 1110-1120. 